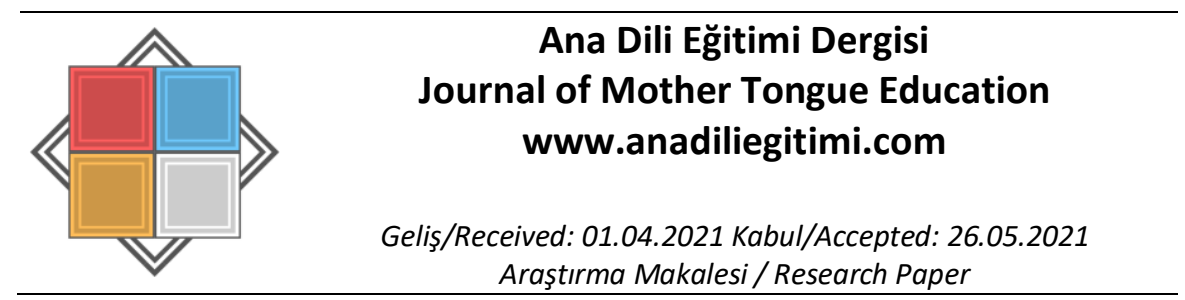

\title{
Sınıf Öğretmeni Adaylarının Okuryazar Pratiklerinin Sosyal Bağlamda İncelenmesi
}

\author{
Ömer Faruk TAVŞANLI*
}

\begin{abstract}
Öz
Bireylerin okuryazarlıkları sosyal bir bağlam içerisinde doğar, gelişir ve kendi okuryazar kimliğini oluşturur. Bu okuryazar kimliğin ise günlük yaşama yansımaları olur. Bu durum öğretmenler için daha önemlidir. Çünkü öğretmenler okuryazarlıklarını sınıf içinde kullanır ve bu durum öğrencilerin okuryazarlıkları ve akademik başarıları başta olmak üzere pek çok becerinin gelişimini etkiler. Bu sebeple öğretmenlerin ve öğretmen adaylarının okuryazarlıklarının sosyal bağlamda incelenmesi gerekli görülmektedir. Sınıf öğretmeni adaylarının okuryazar pratiklerinin sosyal bağlamda incelenmesini amaçlayan bu araştırma fenomenolojik bir araştırmadır. Araştırmada veriler yarı yapılandııılmış görüşmeler, yansıtmacı yazılar ve okuryazarlığı günlük yaşantılarında kullandıklarına yönelik örnek deliller aracılı̆ı̆yla toplanmıştır. Elde edilen veriler içerik analizi tekniğiyle analiz edilmiştir. Araştırmadan elde edilen bulgulara göre sınıf öğretmeni adaylarının okuryazar pratiklerini günlük yaşamda kullanmaları beş farklı şekilde gerçekleşmektedir. Bunlar; akademik, dijital platformlar, günlük pratikler, psikolojik ve sosyal etkileşim.
\end{abstract}

Anahtar Kelimeler: Okuryazar pratikler, sınıf öğretmeni adayları, fenomenoloji

\section{Examining Literacy Practices of Primary School Prospective Teachers in a Social Context Abstract}

Individuals' literacy arises and develops in a social context and creates their own literacy identity. This literate identity has reflections on daily life. This situation is more critical for teachers. Because teachers use their literacy in the classroom, and this affects the development of many skills, especially students' literacy and academic achievement. For this reason, it is necessary to examine the literacy of teachers' and prospective teachers' in a social context. This research, which aims to examine primary school prospective teachers' literacy practices in a social context, is a phenomenological research. The study data were collected through semi-structured interviews, reflective writings, and sample evidence that they use literacy in their daily lives. The datas were analyzed by content analysis technique. According to the research findings, there are five different ways for primary school prospective teachers' to use their literacy practices in daily life. These; academic, digital platforms, daily practices, psychological and social interaction.

Keywords: Literacy practices, primary school prospective teachers, phenomenology

\section{Giriş}

Sosyal bir varlık olan insan doğduğu andan itibaren belli bir topluluk içerisinde diğer bireylerle etkileşime geçer ve bu etkileşimin tüm bireylerin yaşantılarına etkisi olur. Bu etki bireylerin okuryazarlık yaşantılarında da gözlenir. Her bireyin kendini ifade etme tarzı, üslubu ve yöntemi farklıdır. Bireyler benzer konularda aynı şeyleri ifade etmek isteseler bile, sosyokültürel yapıları, kültürel genleri ve dili kullanma şekilleri ile birbirlerinden ayrılırlar. Bu açıdan bireylerin yazma becerilerini kullanma şekilleri ve kapasiteleri de değişkenlik göstermektedir (Barton ve Hamilton, 2000).

Okuma ve yazma daha çok bilişsel olarak ele alınsa da içerisinde bulunulan toplumdan, toplumun davranış kalıplarından, değerlerinden ve inançlarından etkilenir. Bireylerin herhangi bir

\footnotetext{
* Dr. Öğr. Üyesi, İstanbul Aydın Üniversitesi, Eğitim Fakültesi, Temel Eğitim Bölümü, Sınıf Eğitimi ABD, İstanbul, omerfaruktavsanli@gmail.com, ORCID ID: https://orcid.org/0000-0003-1366-1679
} 
alanda yazabilmesi için belli bir donanıma, altyapıya ve birikime sahip olması gerekmektedir. Birey bu birikimi okuyarak, gözlemleyerek, yaparak ya da başkalarından dinleyerek edinir. Bu edinim sürecinde hangi kaynaklara ulaştığı, kimlerle iletişime geçebildiği, kimleri nasıl gözlemlediği kişinin sosyal çevresi ile ilgili bir durumdur. Yani kişi yazacağı konuda sahip olması gereken yapının önemli bir kısmını sosyal çevresi aracılı̆̆ıyla edinir. Bu durum bireylerin anlayış şekillerinin birbirlerinden farklı olmasına sebep olur (Jones-Diaz ve Harvey, 2007). Bu farklılık bireylerin sözlü ya da yazılı aktarımları üzerinde etkilidir (Brandt ve Clinton, 2002). Yazma, bu açıdan bireysel olarak gerçekleşse bile arka planı dolayısıyla bir topluluk eylemi olarak görülebilir. Çünkü kişiler bir metni oluşturma süreçlerinde, metnin muhatabı olacak okuyucu kitlesini belirler. Sonrasında ise okuyucu kitlesinin düzeyine, yapısına, metni anlayış biçimine göre metni yapılandırma işlemine gider. Okuryazarlı̆ın sosyal yapılandırmacı bir perspektifle ele alındığını savunan teorilerde bireyin toplumdan bağımsız bir okuryazarlık yaşantısına girmesi olası görülmez. Yukarıda bahsedilen gerekçelerle birey yazacağı konuyu anlama süreçlerinden bunu eyleme geçireceği süreçlerin bütününde sosyal çevresinden etkilenir (Graham vd., 2018).

Bireyin yaşantısını pek çok alanda etkileyen okuma ve yazma becerilerini geliştirmek tüm eğitim sistemlerinde önemli görülmektedir. Çünkü okuryazarlık aktif bir eylemdir ve bireylerin davranışlarına yansıması vardır. Bu bakımdan bireylerin okuryazarlıkları sosyal çevreden etkilendiği gibi aynı zamanda bireye kattığı davranışlar yoluyla sosyal çevreyi etkiler. Yani birey okuryazarlık davranışları ile sosyal çevresine bir mesaj gönderir veya bu davranışları çevresi tarafından algılanır ve bundan bir anlam çıkartılır. Bu durum okuryazarlığın bireylerin günlük yaşam pratikleri içerisinde yer alması ile ilgilidir (Baynham ve Prinsloo, 2009). Her birey farkında olsun ya da olmasın günlük yaşantısında okuryazarlık becerilerini devamlı kullanır. Bireylerin sosyalleşmesinde, çevresi ile iletişim kurmasında, kendini ve hayatı anlamasında, akademik olarak daha başarılı olmasında bu becerilerin kullanımı kilit bir rol oynamaktadır. Bu açıdan bireyler günlük yaşamın her noktası üzerinde etkisi bulunan bu beceriyi etkin bir şekilde kullanmalı ve bu beceriye dönük sahici bir öz bilince sahip olarak kendini, dili daha etkili kullanan bireyler olarak yetiştirmelidir (Bhola, 1991). Bu durumun bireylerin hem akademik olarak daha başarılı olmasını hem de içerisinde bulunduğu sosyal çevreye daha iyi uyum sağlamış, iletişim becerileri yüksek bireyler olmasına yardımcı olduğu düşünülmektedir (Baynham, 2004). Bu noktada bireylerin okuryazarlığı günlük yaşantısını etkileyecek bir şekilde sosyal bir pratik olarak hangi alanlarda, nasıl kullandığı önemli bir konu haline gelmektedir.

Öğretmenlerin okuryazarlık yaşantılarının incelenmesi ve sosyal bağlamda günlük yaşantılarına nasıl yansımalarının olduğunun ortaya çıkarılması önemlidir. Çünkü öğretmenlerin okuryazarlık yaşantıları sadece kendilerini etkilememektedir. Öğretmenlerin okuryazarlık yaşantıları sınıf içi okuryazarlık çalışmalarını, öğretme yöntemlerini ve öğrencilerin okuryazarlık durumlarını ciddi bir şekilde etkilemektedir. Öğretmenlerin okuryazarlık becerilerinin öğrencilerin okuryazarlık becerilerini etkilediği pek çok çalışma ile ortaya konmuştur (Basma ve Savage, 2018; Ciampa, K. ve Gallagher, 2018; Guo, Connor, Yang, Roehrig ve Morrison, 2012; Pantaleo, 2015; Rice, 2003; Turner ve Paris, 1995).

Öğretmenler kendi pedagojik yaklaşımlarını oluştururken pek çok kaynağa başvurur, diğer eğitmenler ile etkileşime geçer ve kendi zihinsel yapıları gereği bunları bir filtreden geçirerek kendi pedagojilerini oluşturur (Starkey, 2010). Bu oluşturulan pedagojik yaklaşımların okuryazarlık yaşantılarından etkilendiği bilinmektedir (Schachter, 2017). Pedagojik yaklaşımın inşası dışında öğretmenlerin okuryazarlığı sınıf içi bir enstrüman olarak kullanma biçimleri de birbirinden farklılık göstermektedir ve bu farklılık öğrencilerin de farklı yaklaşımlarla karşılaşmasını sağlamaktadır. Yani öğretmenler okuryazarlığı sınıflarında farklı şekillerde uygular/gösterir ve bu da sınıftaki öğrencilerin okuryazarlık yaşantılarını, algılarını, değerlerini etkiler. Bu durum şüphesiz öğrencilerin hem akademik başarılarını hem de okuryazarlık ile elde edilecek entelektüel birikimini etkilemektedir. Yapılan araştırmalar yüksek okuryazarlığa sahip öğretmenlerin öğrencilerinin de yüksek okuryazarlık becerilerine sahip olduğunu ortaya koymaktadır (Guo, Piasta, Justice ve Kaderavek, 2010; Varghese, Garwood, Bratsch-Hines ve Vernon-Feagans, 2016). Okuryazarlık şüphesiz sadece akademik başarıyı ve entelektüel bilgi sahibi olmayı sağlamaz. Aynı zamanda bireylerin farklı kaynaklar aracılığı ile farklı fikirlere ulaşmasını, bu farklı fikirlerin eleştirel analizini yapmasını, farklı hayatları tanımasını ve bu farklııklara saygı duymasını sağlar. Yani aslında okuryazarlık sayesinde bireyler kendi yaşayamadıkları farklı duyguları, yaşantıları anlama; en azından bunların farkında olma fırsatı bulur (Baynham ve 
Prinsloo, 2009). Bu bireyler için ciddi bir kazanımdır. Bunun yanı sıra okuryazarlık sadece anlama becerilerini içermez. Bireyler yazma aracılığı ile aktarma işlemi de yapabilir. Bu yolla edinilen bilgilerin paylaşılması, yakın uzak çevre ile iletişim, içsel rahatlama ve iç dökme gibi eylemlerde bulunulabilir. Bu eylemlerin tamamı bireyin psikolojik olarak daha iyi niteliklere sahip olmasını sağlar. Ayrıca yazma becerisi içerisindeki zor bilişsel süreçler bireyin zihinsel aktivitelerini arttıır ve bilişsel olarak daha güçlü olmasını sağlar. Bu açıdan bakıldığında öğretmenlerin öğrencilerine nitelikli okuryazarlık becerilerini kazandırmasının ne kadar önemli olduğu anlaşılmaktadır. Özellikle ilkokulda, ilk okuryazarlık deneyimlerinin sınıf öğretmeni tarafından yaşatıldığı düşünüldüğünde bu dönem daha kritik hale gelmektedir. Okuryazarlığın bir topluluk ile oluşturulduğu ve etkileşerek geliştirildiği düşünüldüğünde bu topluluğun en önemli parçalarının öğretmenler ve öğrenciler olduğu unutulmamalıdır (Graham vd., 2018). Bu bileşenlerin okuryazarlık anlamında ilk buluştuğu sınıf düzeyi ilkokul olduğu için okuryazarlığın şekillenmesinde sınıf öğretmenlerinin rolünün daha fazla olacağı düşünülmektedir.

\section{Araştırmanın Gerekçesi}

Türk yükseköğretim sisteminde eğitim fakültesi öğrencileri öğretmen adayı olarak ifade edilmektedir. Öğretmen adayları diplomalarını alarak başarılı olduklarında öğretmen olurlar. Yani her öğretmen adayı geleceğin potansiyel öğretmeni olarak görülmektedir. Bu araştırmada da gelecekte sınıf öğretmeni olarak görev yapması muhtemel olan sınıf öğretmeni adaylarının okuryazar pratikleri incelenmiştir. Bu incelemenin en temel gerekçelerinden bir tanesi giriş kısmında ifade edildiği üzere öğretmenlerin okuryazarlık yaşantılarının öğrencilerinin okuryazarlık, akademik başarı, sosyal hayat gibi alanlar üzerinde ne kadar etkili olduğu gerçeğidir. Şüphesiz ki bu etkinin nasıl ortaya çıktığının anlaşııması için öğretmen adaylarının okuryazarlığı günlük hayatlarında nasıl kullandığının ortaya çıkarılması gerekmektedir. Bu durumun tespitinin özellikle okuryazarlığı ele alan öğretmen politikalarının şekillenmesinde etkili olacağı düşünülmektedir. Çünkü okuryazarlı̆ı̆n günlük pratiklerde ele alınma şekli öğretmenlerin pedagojilerini ciddi bir şekilde etkilemektedir (Pantaleo, 2015; Rice, 2003). Böylece araştırma, bu pratiklerin pedagojik yaklaşımları nasıl etkilediği veya etkileyebileceği üzerinde fikir sahibi olunması sağlanacaktır.

íkinci olarak okuryazarlık çalışmaları incelendiğinde okuryazarlığın daha çok bilişsel açıdan ele alındığı, teknik olarak öğretim süreçlerinin daha fazla çalışıldığı görülmektedir (Tavşanlı, Sadioğlu, Onur Sezer ve Kaldırım, 2020). Bununla birlikte okuma ve yazma becerilerinin sosyal pratikler olarak doğduğu, sosyal hayattan etkilendiği ve sosyal hayat ile geliştiği bilinmektedir. Buna rağmen okuryazarlığın bu boyutu hem dünyada hem de Türkiye'de ikinci planda kalmıştır (Flower vd., 1990; Tavşanlı ve Kaldırım, 2020). Bu açıdan okuryazarlığın sosyal hayata yansımaları, günlük yaşamda nasıl kullanıldığı, söylem analizleri, okuryazarlığın bireyin kimliğini nasıl etkilediği gibi konular önem arz etmektedir. Bu araştırmada da özellikle gelecekte öğretmen olacak olan öğretmen adaylarının okuryazar pratiklerinin günlük yaşamda hangi amaçlarla kullanıldığının ortaya çıkartılması amaçlanmaktadır.

Üçüncü olarak Türkiye'de eğitim süreçlerinin gerçek hayattan kopuk olduğu eleştirilmektedir (Eğitim Reformu Girişimi, 2017). Bu açıdan öğrencilerin öğrendiklerini gerçek hayatında uygulama fırsatı bulmadığı çok sık dile getirilen bir eleştiridir. Bu doğrultuda Türkiye'de Millî Eğitim Bakanlığı tarafından basılan "Hayatın İçindeki Müfredat" kitabı bu sürece vurgu yapmakta ve öğretim süreçlerinin günlük yaşamdaki yansımaları gösterilmektedir (Selçuk, 2020). Bu araştırmada da okuryazarlı̆ın günlük hayat pratiklerinde nasıl kullanıldığı ele alınmıştır. Böylece araştırmanın bulgularından hareketle okuryazarlığın günlük hayatta kullanımına yönelik pratik uygulamalar gündeme gelebilir. Bu uygulamalar ve sonrasında gerçekleştirilecek çalışmalar yukarıda bahsedilen çalışmada olduğu gibi okuryazarlığın günlük hayatın içindeki müfredata nasıl adapte edilebileceği konusunda eğitim politikaları belirleyicilere fikir verecektir. Araştırmanın bu bakımdan da önemli olduğu düşünülmektedir. 


\section{Araştırmanın Modeli}

\section{Yöntem}

Bu araştırmada nitel araştırma yöntemlerinden biri olan betimleyici fenomenoloji tercih edilmiştir. Betimleyici fenomenoloji epistemolojik bir yaklaşıma sahiptir ve bireyin bildiği olgunun asılda/özde ne olduğunu sorgular (Ersoy, 2016). Fenomenolojik araştırmalarda bireyin tecrübeleri oldukça önemlidir (Reiners, 2012; Yıldırım ve Şimşek, 2011). Çünkü bu araştırma türünde bireyin bir olguya ait deneyimleri yoluyla oluşturduğu yapı ortaya çıkarılmaya çalışılır. Bu araştırma yöntemi, bir olgu hakkında genel olarak bir yargıya sahip olunsa bile gerçek anlamda anlamlandırmadan ve kavramadan uzak olunan bu yapılar için derinlemesine ve çok boyutlu inceleme imkânı sunar (Creswell, 2012). Bu araştırmada da sınıf öğretmeni adaylarının okuryazarlık yaşantılarının günlük hayata yansımaları incelenmiştir. Herkes okuryazarlığı günlük yaşamda nasıl kullandığı ile ilgili fikir sahibi olabilir. Bununla birlikte okuryazarlığın günlük yaşam pratikleri içinde hangi amaçlarla nasıl kullanıldığının derinlemesine incelenmesi ve bunun sistematik bir şekilde ortaya konması gerekmektedir. Bu sebeple araştırmada sınıf öğretmeni adaylarının okuryazarlık deneyimlerinin günlük yaşantılarına yansımalarının nasıl olduğunu tespit etmek için fenomenoloji yöntemini tercih edilmiştir.

\section{Örneklem / Araştırma grubu}

Fenomenolojik araştırmalarda katılımcılar araştırılan fenomen hakkında deneyimi olan ve bu deneyimi yansıtabilecek bireyler arasında seçilmektedir. Yapılan çalışmanın katılımcılarının belirlenmesinde, ölçüt örnekleme tekniği tercih edilmiştir. Ölçüt örnekleme tekniğine göre daha önceden belirlenmiş ölçütleri sağlayan bireylerin araştırmaya dâhil edilmesi gerekmektedir (Christensen, Johnson ve Turner, 2015). Bu bağlamda araştırmada bireylerin okuryazar yaşantılarına sahip ve bunu aktarabilecek olması araştırmanın katılımcısı olması için ilk koşul olarak belirlenmiştir. Bu koşulu sağlayan pek çok öğretmen adayı bulunmaktadır. Bu sebeple ölçütlerin daraltılması ve hedefe hizmet etmesinin sağlanması adına ek ölçütler belirlenmiştir. Öncelikle öğretmen adaylarının son sınıf olması ek ölçütlerin ilki olarak belirlenmiştir. Bu ölçütün belirlenmesindeki amaç öğretmen adaylarının dil becerileri ve öğretimi ile ilgili müfredatlarında bulunan dersleri almış olmasıdır. Bu derslerin onların okuryazarlıklarını etkileyeceği gerçeğinden dolayı böyle bir ölçüt belirlenmiştir. Bu ölçüt belirlendikten sonra öğretmen adaylarının düşük, orta ve yüksek okuryazarlık düzeylerinin tespit edileceği bir belirtke tablosu hazırlanmış (Tablo 1) ve öğrencilerin hangi sınıflamaya dâhil olacaklarının tespit edilmesine yönelik veri alınmıştır. Bu belirtke tablosu araştırmacı tarafından Fitzgerald, Spiegel ve Cunningham (1991), MacCleod (2004) ve Van Bergen, De Jong, Plakas, Maassen ve Van Der Leij'nin (2012) çalışmaları dikkate alınarak oluşturulmuştur. Bu veriler incelenmiş ve her düzeyden (düşük, orta ve yüksek okuryazarlık) iki öğrenci katııımcı olarak belirlenmiştir. Bu bağlamda araştırmaya toplam altı sınıf öğretmeni adayı dâhil edilmiştir.

Tablo 1.

Okuryazar Düzeyleri Belirtke Tablosu

\begin{tabular}{clll}
\hline $\begin{array}{c}\text { Okuryazarlık } \\
\text { seviyeleri }\end{array}$ & Yüksek Düzey Okuryazar & Orta Düzey Okuryazar & Düşük Düzey Okuryazar \\
\hline Gösterge 1 & $\begin{array}{l}\text { Düzenli olarak günlük } \\
\text { olayları dergi, gazete vb. } \\
\text { platformlardan okur ve } \\
\text { bunları etrafı ile paylaşır. }\end{array}$ & $\begin{array}{l}\text { Zaman zaman günlük } \\
\text { olayları dergi, gazete vb. } \\
\text { platformlardan okur ve } \\
\text { bunları etrafı ile paylaşır ya } \\
\text { da bunlardan bir kısmını } \\
\text { yapar. Örneğin bahsedilen } \\
\text { yayınları okur ama yazarak }\end{array}$ & $\begin{array}{l}\text { Hiçbir zaman günlük } \\
\text { olayları dergi, gazete vb } \\
\text { platformlardan okumaz } \\
\text { paylaşmaz. }\end{array}$ \\
& & paylaşım yapmaz. & \\
& & ilgi duyduğu bir alanda & ilgi duyduğu bir alanda \\
Gösterge 2 & ilgi duyduğu bir alanda & zaman zaman kitap okur. & kitap okumaz.
\end{tabular}


Gösterge 3 Kendini rahatlatmak için okuma yapar (kitap, dergi vb.)

Gösterge 4 Yeni çıkan eserleri takip eder, bunlarla ilgili eleştiri yazılarını/tanıtım bültenlerini okur.

\section{Gösterge 5 Farklı türlerde, farklı} platformlardaki yazıları okur.

Gösterge 6 Yazmayı hayatının bir parçası olarak düzenli ve etkin bir şekilde kullanır (e-mail, sanal platform yazışmaları, mesajlaşma uygulamaları, dilekçe yazma vb.)

Gösterge 7 Rahatlamak, kendini bulmak ve keyif almak için yazar.

Gösterge 8 Okuryazarlığın önemine inanır ve bu inancı doğrultusunda davranış örüntüleri sergiler.

\section{Gösterge 9 Okuma ve yazma} becerilerinin daha iyi olması için çaba gösterir ve kendini geliştirmek ister. Buna yönelik eyleme geçer.

\section{Gösterge 10 Günümüzde okuryazarlık} becerilerinin çeşitlendiğini bilir ve ilgili alanlardaki yetkinliğini arttırmak için bu okuryazarlık becerilerini arttırmaya çalışır (finans okuryazarlı̆̆ı, medya okuryazarlığı, bilgi okuryazarlığı vb.)
Kendini rahatlatmak için zaman zaman okuma yapar (kitap, dergi vb.)

Zaman zaman yeni çıkan eserleri takip eder, bunlarla ilgili eleştiri yazılarını/tanıtım bültenlerini okur.

Zaman zaman farklı türlerde, farklı platformlardaki yazıları okur.

Yazmayı zaman zaman ve işini görecek kadar kullanır (e-mail, sanal platform yazışmaları, mesajlaşma uygulamaları, dilekçe yazma vb.) (Bu sayılan maddelerden bir ya da ikisi)

Zaman zaman rahatlamak, kendini bulmak ve keyif almak için yazar.

Okuryazarlı̆ıın önemine inanır ve ama bunu davranış örüntülerinde göremeyiz.

Okuma ve yazma becerilerinin daha iyi olması için çaba gösterir ve kendini geliştirmek ister ama eyleme geçme konusunda tutukluk yaşar.

Günümüzde okuryazarlık becerilerinin çeşitlendiğini bilir ama ilgili alanlardaki yetkinliğini arttırmak için bu okuryazarlık becerilerini arttırma gayreti eksiktir ya da yoktur (finans okuryazarlığı, medya okuryazarlı̆̆ı, bilgi okuryazarlığı vb.)
Kendini rahatlatmak için okuma yapmaz.

Hiçbir zaman yeni çıkan eserleri takip etmez, bunlarla ilgili eleştiri yazılarını/tanıtım bültenlerini okumaz.

Farklı türlerde, farklı platformlardaki yazıları okumaz.

Yazmayı hayatının bir parçası olarak görmez ve kullanmaz.

Rahatlamak, kendini bulmak ve keyif almak için yazmaz.

Okuryazarlığın önemine inanmaz.

Okuma ve yazma becerilerinin daha iyi olması için herhangi bir çaba göstermez.

Okuryazarlık becerilerinin çeşitlendiğini bilmez ve bununla ilgilenmez. 


\section{Veri Toplama Araçları}

Araştırmada veriler yarı yapılandırılmış görüşmeler, yansıtmacı yazılar ve okuryazarlı̆̆ı günlük yaşantılarında kullandıklarına yönelik örnek deliller aracılığıyla toplanmıştır. Görüşme yöntemi ile veri toplamadaki asıl amaç katılımcılardan belli soruların cevaplarını almak değildir. Asıl önemli olan araştırılan konuda kişisel bir bakış açısı ve araştırılan konuyu anlamlandırma mekanizmalarını ortaya çıkarmaktır (Barriball ve While, 1994). Yarı yapılandırılmış görüşmelerde, görüşmeciler daha derinlemesine inceleme yapabilmek için hazırladıkları soruların dışına çıkmakta ve ek sorular sormakta özgürdürler (Berg, 2000; Patton, 1990). Böylece katılımcıların anlatmak istediği noktaların ve hikâyelerin eksik kalmayacak şekilde elde edilmesi sağlanmış olur (Barriball ve While, 1994). Araştırmada, yarı yapılandırıımış görüşme tekniğinin tercih edilme sebebi, araştırmacılara bu esnekliği sağlamasıdır. Bu noktada görüşme yapılan kişilerin dolaylı bilgiye sahip olan kişilerden seçilmemiş olması önem taşımaktadır. Görüşmeye katılacak kişilerin araştııılan konuyu bizzat deneyimlemesi gerekmektedir (Rubin ve Rubin, 2005). Araştırmanın katılımcıları bu görüşme ilkeleri ile uyumlu olacak şekilde seçilmiştir.

Yarı yapılandırılmış görüşme formunun soruları hazırlanırken ilgili alanyazın taranmış, ek olarak üç sınıf öğretmeni, iki Türkçe Eğitimi uzmanı ve iki dil pratikleri (dilin günlük yaşamda kullanımı) uzmanlığı olan akademisyen ile görüşülmüştür. Yapılan ön görüşmeler ve alanyazın taraması sonucunda öğretmen adaylarına yöneltilmek üzere yirmi üç sorudan oluşan yarı yapılandırılmış görüşme formunun ilk hali hazırlanmıştır. Araştırmacılar tarafından geliştirilen görüşme sorularının hazırlanması esnasında soruların kolaylıkla anlaşılması, çok boyutlu olmaması, yanıtlayıcı ve yönlendirici olmaması gibi ilkelere dikkat edilmiştir. Illgili form uygulanmadan önce görüşlerine başvurulan uzmanlara tekrar sunulmuştur. Uzmanlardan gelen görüş ve öneriler doğrultusunda on bir soru görüşme formundan çıkarılmış; bazı sorularda ise düzenlemeler yapılmışır. ilgili düzenlemeler sonucunda on iki sorudan oluşan yarı yapılandırılmış görüşme formu uzmanlara tekrar gönderilmiş ve gelen dönütler doğrultusunda formun çalışma için uygun olduğuna karar verilmiştir. Öğretmen adayları ile asıl görüşmeler yapılmadan önce çalışma grubuna dâhil olmayan iki öğretmen adayı ile pilot görüşme gerçekleştirilmiştir. Pilot görüşmeler sırasında görüşme sorularının belirlenen amaca yönelik olup olmadığı ve öğretmen adayları tarafından anlaşılıp anlaşılmadığı kontrol edilmiştir. Yapılan pilot görüşmeler sonucunda üç sorunun benzer şekilde anlaşılıp cevaplandığı tespit edildiğinden bu üç soru birleştirilmiştir. Böylece 10 sorudan oluşan yarı yapılandırılmış görüşme formuna son hali verilmiştir.

Araştırmada ayrıca öğretmen adaylarından okuryazar yaşantılarına yönelik yansıtmacı yazılar yazmaları ve okuryazarlığı günlük yaşantılarında kullandıklarına yönelik örnek deliller sunmaları istenmiştir. Elde edilen yansıtmacı yazılar ve deliller de verileriz analiz sürecine dâhil edilmiş ve analizlerin desteklenmesinde kullanılmıştır.

\section{Veri Toplama Süreci}

Araştırmanın verileri, katılımcılar belirlendikten sonra hazırlanan görüşme formları, yansıtmacı yazılar ve öğretmen adaylarından istenen deliller aracılığıyla toplanmıştır. İlk aşama olarak öğretmen adaylarından okuryazar geçmişlerine ve okuryazarlığı günlük yaşantılarında nası//nerede kullandıklarına yönelik yansıtmacı yazılar yazmaları istenmiştir. Öğretmen adaylarından ilgili yazılar alındıktan sonra veri toplama aşamasının ikinci boyutuna geçilmiştir. Bu aşamada öğretmen adayları ile yarı yapılandırılmış görüşmeler gerçekleştirilmiştir. Öğretmen adayları ile gerçekleştirilen görüşmeler Zoom programı kullanılarak yapılmış ve her bir görüşme kayıt altına alınmıştır. Her görüşme 25-50 dakika arasında sürmüştür. Görüşmeler sonrasında Zoom programı aracılığıyla elde edilen verilerin yazılı dökümleri çıkartılmıştır. Bu aşamada üç saatlik Zoom kaydı transkript edilmiş ve 28 sayfa yazılı döküm elde edilmiştir. Sonrasında elde edilen yazılı dökümler titiz bir şekilde incelenmiştir. Bu transkriptler başka bir araştırmacı tarafından, Zoom programı aracılığıyla elde edilen kayıtlar ile karşılaştııılmıştır. Son olarak ise öğretmen adaylarından okuryazarlığı günlük yaşamda kullandıklarına yönelik deliller getirmeleri (not defterleri, okudukları kitaplar, mesajlaşmalar, sosyal medya kullanımları gibi) istenmiştir. Bu aşama da tamamlandıktan sonra üç aşamalı olan veri toplama süreci sona ermiştir. 


\section{Verilerin Analizi}

Araştırmanın verilerinin analizinde içerik analizi tekniği kullanılmıştır. İçerik analizi, herhangi bir metnin, görünümsel yapısından ziyade içeriğine odaklanan ve metni derinlemesine ele alarak içyapılarını ortaya çıkartan bir yöntem olarak tanımlanmaktadır (Berelson, 1952; Cavanagh, 1997). Bu analiz yönteminin kullanılması ile metinlerin içerisindeki her bir yapının analiz edilmesi ve bu yapıların ortaya koyduğu ve temsil ettiği bağlamın ortaya çıkarılması ve bu yapılar arasındaki ilişkileri ortaya koyarak metnin bütününde ne söylendiğinin anlaşılması hedeflenmektedir (Merriam, 1998). Bu yolla incelenen olgunun derinlemesine anlaşılması sağlanmış olur (Downe-Wamboldt, 1992). Bu bilgi edinme işlemi, araştırılan konudaki ham verinin sınıflanarak, kod, alt tema ve temaların elde edilmesi ve bu yolla açık ve gizil anlamlara ulaşılması yoluyla gerçekleşir (Merriam, 1998). Bu araştırmada da öğretmen adaylarının okuryazarlığı günlük yaşam pratiklerinde nasıl ve hangi amaçlarla kullandığının ortaya çıkarılması hedeflenmektedir. Bu hedefe ulaşılmasında öğretmen adayları ile gerçekleştirilen görüşmelerin yukarıda anlatıldığı şekilde detaylı bir analizinin yapılması gerektiğinden içerik analizi yöntemi tercih edilmiştir. Görüşmelerin analizleri yapılırken, yansıtmacı yazılar ve öğretmen adaylarından alınan dokümanlar da dikkate alınmış ve çalışmada bu veriler de tema ve alt tema oluşturma süreçlerinde kullanılmıştır. Araştırmada elde edilen verilere göre temaların ve alt temaların oluşturulması sürecinde iki araştırmacı bir araya gelerek uzlaşıya varmışlardır. Araştırmanın güvenirliği "Güvenirlik = Görüş birliği / (Görüş birliği + Görüş Ayrılığı) x 100" formülü kullanılarak hesaplanmıştır (Miles ve Huberman, 1994). Araştırmacılar arasındaki güvenirlik oranı \%92 olarak bulunmuştur. Araştırmanın bulgularının sunumunda gerçekleştirilen görüşmeler ve yazılı yansıtmalardan birebir alıntılar yapıımıştır. Etik kurallar gereği bu alıntılar verilirken öğretmen adaylarının isimleri anonim bir şekilde, ÖA1, ÖA2,.... ÖA6 olarak verilmiştir.

\section{İnanırlık}

Toplanan veriler az sayıda katılımcıdan alınmış olsa da nitel araştırmanın doğasına uygun geçerlilik standartlarını karşılamak için başka teknikler sürece dâhil edilmiştir. İlk olarak, verilerin birbirini desteklenmesi, daha derin bir anlam elde edilmesi ve incelenen fenomenin daha iyi anlaşılması için (Huberman ve Miles, 1994) üç farklı veri toplama yöntemi sürece koşulmuş ve metodolojik bir üçgenleme kullanılmıştır (Patton, 1980). İkincisi, araştırmacı, yazar görüşme protokolünün yapılandırılması, araştırmanın sürdürülmesi ve analiz süreçlerinde meslektaşları ile devamlı bir şekilde görüşmüş ve fikir alışverişinde bulunmuştur. Özellikle veri toplama araçlarının belirlenmesi, veri toplama süreci ve verileriz analizinde meslektaşlara sürekli olarak bilgi verilmiş ve süreçle ilgili görüşleri alınmıştır. Meslektaşlarla olan bu etkileşimler, meslektaşlardan bilgi toplama süreçlerine hizmet etmiş ve araştırmanın yanlış yapılandırıması önlenmiştir (Lincoln ve Guba, 1985). Böylelikle araştırmanın geçerliliği desteklenmiş olmuştur. Üçüncüsü, yerleşik kodları, temaları ve modeli yeniden doğrulamak için telefon görüşmeleri ve katılımcı ile e-postalar yoluyla kontrol yapılmıştır. Böylece, veriler analiz edildikten sonra bile, katılımcılardan söylemlerin kod temalarına uygunluğu değerlendirilmiştir. Bu sayede veri toplama sürecinin başından raporlama sürecinin sonuna kadar inandırıcılığı sağlamak için aksiyonlar alınmıştır.

\section{Araştırma ve Yayın Etiği}

Bu çalışmada "Yükseköğretim Kurumları Bilimsel Araştırma ve Yayın Etiği Yönergesi" kapsamında uyulması belirtilen tüm kurallara uyulmuştur. Yönergenin ikinci bölümü olan "Bilimsel Araştırma ve Yayın Etiğine Aykırı Eylemler" başlığı altında belirtilen eylemlerden hiçbiri gerçekleştirilmemiştir.

\section{Etik Kurul izni}

Kurul adı = İstanbul Aydın Üniversitesi Sosyal Bilimler Etik Komisyon Kararı

Karar tarihi $=03.03 .2021$

Belge sayı numarası $=2021 / 2$ 


\section{Bulgular}

Araştırma kapsamında elde edilen verilere göre sınıf öğretmeni adaylarının okuryazarlığı günlük yaşam pratikleri içerisinde beş farklı şekilde kullandığı tespit edilmiştir. Bu temalar; akademik, dijital platformlar, günlük pratikler, psikolojik ve sosyal etkileşim temalarıdır. Bu temaların her birinin altında belli alt temalar bulunmaktadır. Toplamda 12 alt tema elde edilmiştir. Bu durum katılımcıların beş tema altında 12 farklı şekilde okuryazarlığı günlük yaşantısında kullandığını ortaya koymaktadır. Sınıf öğretmeni adaylarının okuryazar pratiklerini gösteren görsel Şekil 1'de gösterilmiştir.

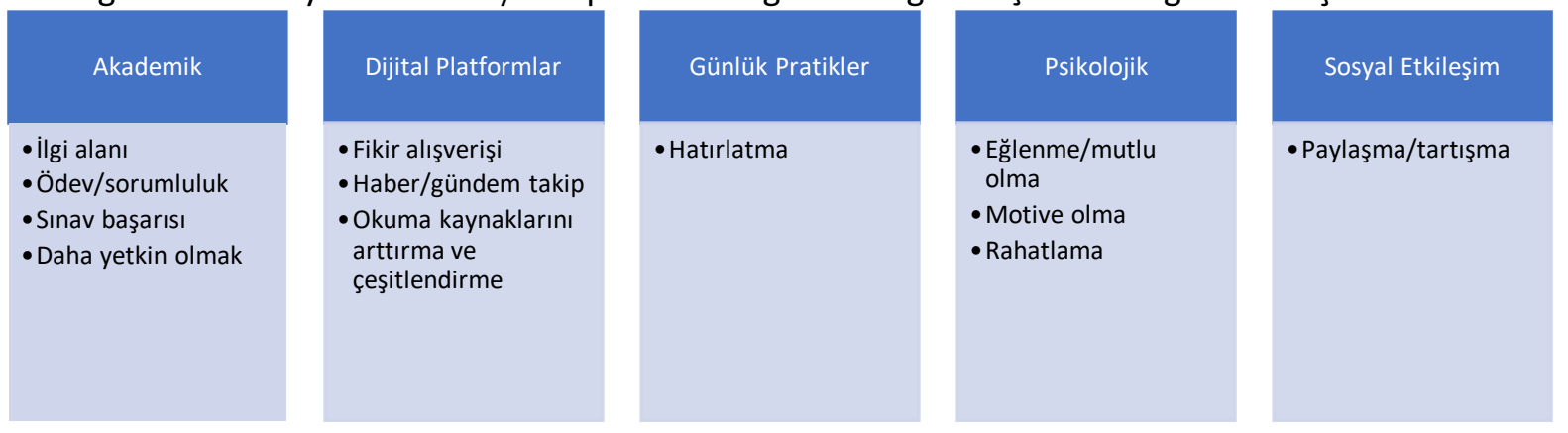

Şekil 1. Sınıf Öğretmeni Adaylarının Okuryazar Pratiklerini Gösteren Görsel

Sınıf öğretmeni adaylarının okuryazar pratiklerini yansıtan temalardan ilki akademik yaşam temasıdır. Elde edilen verilerden öğretmen adaylarının okuryazarlığı akademik yaşantıları doğrultusunda kullandığı ortaya çıkarılmıştır. Öncelikle öğretmen adaylarının kendi okudukları program olan eğitim programları ile ilgili okuryazar yaşantılarına sahip olduğu tespit edilmiştir. Bu bağlamda öğretmen adayları kendi branşları özelinde okumalar yapmış ve bunları yazılı olarak da kullanmıştır. Bu alt tema ilgi alanı olarak isimlendirilmiştir. Öğretmen adaylarının söylemlerinden örnekler aşağıdaki gibidir:

ÖA1: "Onun dışında bölümümü de sevdiğim için bölümümle ilgili kitaplar okumak da sevdiğim çalışmalardandır. Bu sebeple lise ile üniversite benim için çok farklı."

ikinci alt tema ödev/sorumluluk alt temasıdır. Öğretmen adayları üniversite ve daha önceki öğretim süreçlerinde ödev yapma gerekliliği ve sorumluluğundan dolayı okuryazarlığı kullanmıştır. Bu alt tema bir önceki ilgi alanı alt temasından farklıdır. Çünkü ilgi temasında okuryazarlığı kullanmak için herhangi bir zorunluluk yokken burada okuryazarlığı kullanmak kişisel tercihten ziyade zorunluluk ya da bir sorumluluk alanı olarak görülmektedir. Örneğin:

ÖA2: "Yansıma raporu yazdık her hafta. Bir de bizim ikinci sınıf çok yoğun geçmişti. Fen dersinde rapor yaz, yansıtma yaz. Felsefe, sosyoloji dersleri var onlarda yazı yaz. Sürekli yazı yazmaktan artık hızlandım diye düşünüyorum. Okuryazarlı̆ı bu açıdan çok kullandığımı düşünüyorum."

ÖA6: "Yazma okumaya göre kıyasla daha az kullanıyorum. Ama şu yaptığımız ödevlerde okumanın yanında yazmanın da sürekli kullanıldığını görebiliyorum."

Öğretmen adayları okuryazarlı̆ı̆ sınav başarısını da etkilediğini ifade etmiştir. Bu anlamda okuryazar kişilerin daha başarılı olduğunu ya kendileri yaşamış ya da çevrelerinde bunu gözlemlemiştir. Bu durum da öğretmen adaylarının okuryazarlığı günlük yaşamda kullanmalarına sebep olduğu görülmektedir.

ÖA4: "Çok okumam ya da okumaya çalışmam paragraf sorularında işime yaradı. Paragraf sorularını çok hızlı çözüyorum. Bu da benim sınavlarda daha iyi olmamı sağladı."

ÖA6: "Üniversite ile beraber okula girişten itibaren hocalar makale atıyor. Oradan makale alışkanlığı var yani okuma olarak. Sınavlardan daha yüksek almak için okuyorum tabii."

Öğretmen adayları akademik teması altında son olarak alanlarında daha yetkin bireyler olmak için okuryazarlığı kullandığını ifade etmiştir. Bu bağlamda eğitim ve özel olarak bakıldığında sınıf öğretmenliği alanında öğretmen adaylarının yetkinliklerini arttırmak için okuryazarlığı kullandığı görülmektedir. Örneğin:

ÖA5: "Üniversiteden önce makale okuduğumu hatırlamıyorum. Üniversite tabii daha akademik yaşama girdiğimiz için makale okumamız gerekiyordu. Makale okumayı öğrendim, daha fazla 
okur hale geldim. Makalelerden bir şeyler çıkartıyoruz. Bu konuda geliştim üniversitede. Alanımla ilgili daha yetkin biri olmamın köşe taşları bunlar."

ÖA3: "Başlarda makaleler çok sıkıcı geldi. Çünkü akademik kelimeler, birden değişen cümleler, farklı tarzlar, yazı üslupları zor geldi. Ama sonrasında şöyle dedim. Çevrene bak! Insanların çoğu okuryazar değil ama sen eğitim fakültesinde okuyorsun ve okuryazar bir birey olmak zorundasın ve üstelik hani saygı göreceksin ve bu saygının da hakkını da verebilmen lazım."

Öğretmen adaylarıyla gerçekleştirilen görüşmeler ve yazılı yansıtmalardan elde edilen ikinci tema ise dijital platformlar temasıdır. Bu tema altında öğretmen adayları dijital platformları günlük okuryazarlık yaşantılarında nasıl kullandıklarını dile getirmiştir. Teknolojinin günümüz dünyasındaki yeri ve önemi düşünüldüğünde dijital platformlarda okuryazarlık çalışmalarının ne amaçla/nasıl kullanıldığııın ortaya çıkarılmasının önemi daha iyi anlaşılmaktadır. Bu bağlamda öğretmen adayları ilk olarak fikir alışverişi yapmak için dijital platformlarda okuryazarlık çalışmalarını yaptıklarını ifade etmiştir.

ÖA1: "Sosyal medyada bir uygulama var mesela. Bin kitap diye bir uygulama. Burada kendi okuduğum kitapların listesini oraya da ekliyorum. Oradan puanlar veriyorum. Bir kitabın ismine tıkladığımda o kitap hakkında eleştirilerde bulunmuş insanların fikirlerini görüyorum. Yorumlar görüyorum. Kimler beğenmiş, kimler beğenmemiş, ne kadar beğenilmiş bunlara erişebiliyorum."

ÖA5: "Evet, ben de kitap tavsiyeleri alıyorum. Özellikle kitap tavsiyeleri veren hesaplar var. Bir tane takip ediyorum. Öyle bir hesap; oradan tavsiye alıyorum ya da gönderi altına ya da hikâye paylaşımları altını okuyorum."

Öğretmen adaylarının dijital platformlardan okuryazarlık yapmasının bir diğer sebebi ise haber ve gündemi takip etme isteğidir. Öğretmen adayları düzenli olarak dünyadaki gelişmeleri takip etmek, bunları anlamak, yorumlamak ve çevresine aktarmak için dijital platformlarda okuryazarlık çalışmaları yapmaktadır. Örneğin:

ÖA2: "Internetten gazete çok okurum ben. Gündemi takip etmeye çalışıorum. Twitter çok okuyorum. Sürekli gündemi takip ederim ben. Benimle bağdaşan bir özellik."

ÖA6: "Yani günümüzde internet var hocam işte, internette haber mutlaka herkes okuyordur. Haber okuyorum ben de. Bunları paylaşıyorum."

Son olarak öğretmen adaylarının dijital okuryazarlık ortamlarını kullanma gerekçeleri olarak okuma kaynaklarını arttırma ve çeşitlendirme amaçlarını taşıdığı görülmüştür. Dijital kaynakların ulaşııması kolay olduğunun altını çizen öğretmen adayları, normalde erişme imkânı olmayan kaynaklara dijital platformlar sayesinde erişebildiğini ifade etmiştir.

ÖA2: "Benim lise sondan beri dünya çevrelerinden arkadaşlarım vardı. Internet ortamım sayesinde. ingilizce öğrenme programları falan var. Hatta ben lisede şey yapıyordum. Bir şarkıcı seçiyordum. Takipçilerinden birini bulup mesaj atıyordum mesela direkt. Diyordum ki adım bu. Türkiye'de yaşıyorum. Ingilizce ögrenmek istiyorum. Acaba yardımcı olur musun diyordum. Küçüklügümden beri yapıyorum ve olumlu cevap veriyorlar. Yabancı bir dilde yayın takip etme şansı tanıdı bana bu. Okuryazarlık penceremi genişletti."

ÖA3: "Bir bilgiye erişmem gerekiyor mesela. Normalde ansiklopediler, kitaplar okumam lazım. Ama internet aracılığıyla çok kolay. Yanımda taşımıyorum, kaybetme olasılığım az. Sonra girdiğimde ona farklı bilgiler eklenebiliyor. Yani bilgi kendini de güncelliyor."

Öğretmen adayları okuryazarlığı günlük pratikler olarak hatırlatma amaçlı kullandığını ifade etmiştir. Çeşitli sebepler dolayısıyla öğretmen adayları gün içerisinde hatırlatma amaçlı mesajlar yazmakta ve bunları birilerine iletmek istemektedir. Iletişimin temelini oluşturan bu durum zaman zaman farklı bireylere zaman zaman da kendine yapılan hatırlatmaları kapsamaktadır. Örneğin:

ÖA2: "Ders notu alıyoruz mesela şimdi, staj yapıyorum. Ben Türkçe dersinde yaptığımız şeyleri kelime olarak yazıyorum. Mesela bu, yazıyorum üç kelimelik bir cümle. Ama ben tüm yapıyı hatırlıyorum. Kelime yazarak not alıyorum. Açık kapı bırakıyorum. Aslında o kelimeyi neden yazdığımı da biliyorum."

ÖA6: "Bir şeyleri hatırlamak için not tutarım hocam en çok. Mesela yapacağım ödevleri, işleri gibi şeyler. Zaman zaman kâğıda zaman zaman da telefona yazarım bunları." 
Öğretmen adaylarının okuryazarlığı günlük yaşantılarında nasıl ve ne amaçla kullandığına ilişsin elde edilen bir diğer tema ise psikolojik etkenleri içermektedir. Öğretmen adayları eğlenme/mutlu olma, motive olma ve rahatlama amaçları ile okuryazarlık çalışmaları yaptıklarını ifade etmiştir. Bu durum okuryazarlığın kullanımında psikolojik etkilerin ve ihtiyaçların önemini ortaya koymaktadır. Bu bulgu aynı zamanda her bireyin psikolojik olarak daha iyi olmak için okuryazarlığı kullanabileceğine yönelik ipuçları taşımaktadır.

ÖA5: "Edebi kitaplar okuyorum, romanlar da okuyorum. Anlam yönünden; yani teorik bilgi veren kitapları nadiren okurum. Sadece ilgimi çeken kitaplar varsa okurum, daha çok edebi yönü ağırlıkı romanlar tercih ediyorum. Beni mutlu eden şeyleri okuyorum. Inanın çok iyi hissediyorum." (eğlenme/mutlu olma)

ÖA6: "Hocam şimdi aslında ilk ilgi duyduğum spor alanında ünlü futbolcuların Messi'dir, Cristiano Ronaldo gibi sporcuların biyografilerini okuyarak başladım aslında. Beni oldukça mutlu etti ve ben de okumaya devam ettim." (eğlenme/mutlu olma)

ÖA1: "Yaklaşık üç senedir okuduğum her kitabı ne zaman başladığımı, ne zaman bitirdiğimi, on üzerinden kaç puan verdiğimi düzenli bir şekilde yazıyorum. Beni çok motive ediyor. Bunu yaptıkça daha çok okuma alıskanlığı kazandım diyebilirim. Telefona yazıyorum notlar kısmına, oradan da silinir diye ayrı bir defter tutuyorum." (motive olma)

ÖA1: "Pandemide özellikle bu dönemde başladım. Günlük yazıyorum. Kendi duygu düşüncelerimi yazmak beni çok rahatlatıyor. Kimse ile paylaşmıyorum kendime özel. Yani genelde günlükte gün içerisinde yaptığım şeyleri değil de daha çok hissettiğim şeyleri yazmayı seviyorum. Bir duyguyu yoğun hissediyorsam eğer onu kâğıda aktardığımda çok daha rahatlamıs hissediyorum. Mutlu olmaktan ziyade içimi birini anlatmaktan daha çok yazarak anlattığımda daha arınmış hissediyorum açıkçası. Içimde tutmanın vermiş olduğu sıkıntıyı atıyorum. Mutlu olduğumda üzgün olduğumda, bir duyguyu yoğun yaşadığımda aktarınca rahatlıyorum."

Öğretmen adaylarının okuryazarlığı günlük yaşamda kullanımına ilişkin son tema sosyal etkileşim temasıdır. Bu tema altında öğretmen adayları sosyal çevrelerindeki bireylerle etkileşime geçmek, onlara okuduklarını anlatmak, yazdıklarını göstermek ve onlardan haber/mesaj almak için okuryazarlığı kullandığını ifade etmiştir. Bu söylemlerde özellikle kardeş ve yakın arkadaş faktörü ön plana çıkmıştır.

Öğretmen adaylarının okuryazarlığı sosyal etkileşim için kullanmaları dilin doğasında yer alan etkileşimi içermesi ve öğretmen adaylarının okuryazarlığı sadece bilgi edinmek için yapmadığını göstermesi açısından önemlidir. Öğretmen adayları bu tema altında aşağıdaki söylemleri dile getirmiştir:

ÖA1: "Sosyal çevremde mahalleden arkadaşlarım var. Biri psikologluk okuyor, şu an son sınıf öğrenci. Diğeri mimari restorasyon bitirdi. Bu iki arkadaşım da okumayı kendini geliştirmeyi seven, okuryazar bireyler olduğunu düşünüyorum. Onlarla da çeşitli kitap tartışmaları yapıyoruz. Dün hatta okuduğu kitaplar üzerinden konuşmuştuk. Çevremde de okuryazar diyebileceğim arkadaşlarım var açıkçası."

ÖA5: "Okuma kültürünü ikizim ve ben ortaokul öğretmenlerimizden edindik. Aynı okul aynı sınıftaydık. Bir şekilde ya da biz kendimiz keyifli bularak geliştirdik. Bence ikizim olması olumlu etkiledi. Çünkü bir kitabı okumak çok önemli ama paylaştığında, fikirlerini paylaştığında çok daha zevkli hale geliyor. Benim hep yanımda biri vardı bu konuda hep beraber okuduk. Bu bence bizi oldukça olumlu etkiledi. Hep paylaştık biz, konuştuk, kitaplardan yorum yaptık, birbirimize önerdik. Ikimizi de bu noktada iten bir güç oldu."

ÖA6: "Kardeşimle üç yaş var aramızda. O da üniversiteye gidiyor. Biz etkiledik kesinlikle birbirimizi. Biz aramızda kitap muhabbeti yapıyoruz. Ben kitap aldıktan sonra o da okuyor. Ya da kitaplar hakkında konuşuyoruz; şu kitapta şu vardı diye anlatıyor, yani böyle iletişimlerimiz var." 


\section{Tartışma ve Sonuç}

Araştırmadan elde edilen bulgulara göre sınıf öğretmeni adaylarının okuryazar pratiklerini günlük yaşamda kullanmaları beş farklı şekilde gerçekleşmektedir. Bunlar; akademik, dijital platformlar, günlük pratikler, psikolojik ve sosyal etkileşim. Öğretmen adaylarının akademik olarak okuryazarlığı ilgi alanları doğrultusunda kullanma, ödev ve sorumluluklarını yerine getirme, sınav başarısı ve daha yetkin bireyler olma yolunda kullandığı ortaya çıkarılmıştır. Günümüz hayat koşullarının vazgeçilmez bir gerçeği olan dijital platformlar da öğretmen adaylarının okuryazarlığı kullanmada dile getirdiği önemli temalardan birini oluşturmaktadır. Bu tema altında fikir alışverişi, haber ve gündemi takip etme, okuma kaynaklarını arttırma ve çeşitlendirme amaçlarıyla okuryazarlık çalışmalarının yapıldığı görülmektedir. Günlük pratikler de okuryazarlığın kullanımını gerekli kılan temalardan bir tanesidir. Bireylerin kendisine ya da bir başkasına hatırlatma yapma gerekliliği bu kullanımı sağlamaktadır. Öğretmen adaylarının okuryazarlığı kullanma gerekçelerinden bir tanesi de psikolojik etki olarak tespit edilmiştir. Bu tema altında eğlenme, mutlu olma, motive olma ve rahatlama gibi gerekçelerle okuryazarlık kullanılmaktadır. Araştırmada son olarak sosyal etkileşim için okuryazarlığın kullanıldığı ortaya çıkarılmıştır. Bu tema altında fikirlerin, düşüncelerin, okunulanların ve hislerin paylaşılması ve tartışıması amacıyla okuryazarlık becerilerinin kullanıldığı görülmektedir.

Türkiye ve dünya eğitim sistemleri incelendiğinde her öğrencinin başarılı olmasının önemi üzerinde durulduğu görülmektedir (Balcı, 2015). Akademik başarı tüm ülkelerin eğitim sistemlerinde önemsenen, nitelikli, kendini geliştirebilen bireylerin yetişmesi için gerekli görülen bir koşuldur. Bu koşulun sağlanmasında akademik başarıyı yalnızca belli bir alandaki sınav başarısı olarak görmek doğru değildir. Aksine akademik başarı, süreci ele alan ve bireyin bütüncül değerlendirildiğinde başarısını ifade eden bir kavramdır (Toptaş, 2011). Bu açıdan yalnızca sınavlara odaklı bir kavram değildir. Bireylerin ilgi alanları doğrultusunda okumalar yapması, ödevler ve okul ile ilgili sorumluluklarını yerine getirmesi ve daha yetkin bireyler olma yolunda kendine hedefler koyarak okuryazarlık çalışmaları yapması bu sürecin parçalarını oluşturmaktadır.

Akademik başarıyı sağlayan pek çok etken vardır ve bu etkenlerin başında okuma ve yazma gelmektedir. Yapılan pek çok araştırma bireyin okuryazarlık düzeyi ile akademik başarısı arasında pozitif yönlü yüksek bir ilişki olduğunu ortaya koymuştur (Cooper, Moore, Powers, Cleveland ve Greenberg, 2014; Craswell ve Poore, 2011; Preiss, Castillo, Grigorenko ve Manzi, 2013; Strong, Silver, Perini ve Tuculescu, 2002; Whitten, Labby ve Sullivan, 2016). Bu açıdan öğretmen adaylarının da akademik başarıyı sağlamak amacıyla okuryazarlık çalışmaları yapması arzu edilen bir durumdur.

Bireylerin akademik olarak kullandığı okuryazarlığın farklı sebepleri olabilir. Her bireyin ilgi duyduğu alanlar vardır. Bireyler bu alanlarda çalışmalar yaparken daha iyi motive olur ve yapmak istediklerini eylemleri daha mutlu bir şekilde yaparlar (Kamler, 2001). Okuryazarlık çalışmalarında da bu durum geçerlidir. Her bireyin okumaktan veya yazmaktan keyif aldığı ilgi alanları bulunmaktadır. Bu ilgi alanlarında derinleşmek ve kendini geliştirmek için okuma ve yazma çalışmaları yapmak gerekli görülmektedir. Springer, Harris ve Dole (2017) yaptığı araştırmada ilgi alanları doğrultusunda okuyan bireylerin daha az stres yaşadıklarını ortaya çıkarmıştır. Bu açıdan ilgi alanları doğrultusunda okuryazarlık çalışmaları yapmak bireyler için oldukça olumlu görülmektedir.

Ödev ve okulda verilen çalışmaların yürütülmesinde de okuryazarlık oldukça önemlidir. Öğrenmenin temelini oluşturan okuryazarlık çalışmaları bir ödev yaparken ya da okuldaki bir görevi yerine getirirken kullanmak zorunda olduğumuz becerilerin başında gelmektedir (Nelson, 1990). Yapılan araştırmalar bireylerin okuryazarlık düzeylerinin yaptıkları ödevlerin niteliğiyle ilişkili olduğunu ortaya koymuştur (Guo vd., 2010; Matsumura, Patthey-Chavez, Valdés ve Garnier, 2002). Bu bağlamda bireylerin okuryazar düzeyleri ne kadar iyiyse yaptıkları ödevler de o kadar niteliklidir denilebilir. Tabii ki bireyin okuryazarlık becerilerinin gelişimi için pek çok koşul bulunmaktadır. Bununla birlikte okuryazarlığı bir alışkanlık haline getirerek düzenli çalışmalar yapmak bunun başında gelmektedir. Bu açıdan bakıldığında her öğrencinin akademik yaşantısında pek çok kere ödev yaptığı ve okuldaki görevlere katıldığı düşünüldüğünde okuryazarlık becerisinin oldukça fazla kullanıldığı ortaya çıkmaktadır.

Dijital platformlar günümüzde neredeyse herkesin kullandığı, özellikle çocuklar ve gençler arasında kullanımı oldukça yaygınlaşan bir alan olarak karşımıza çıkmaktadır. Yapılan çalışmalar dijital 
platformların kullanımının büyüklüğü açısından bize fikir vermektedir. Örneğin; "Digital in 2017: Global Overview" raporunda dünyada neredeyse dört milyar insanın aktif internet kullanıcısı olduğu ifade edilmiştir. Türkiye' de ise günde neredeyse yedi saatin internette geçirildiği, dört saate yakın bir sürenin ise sosyal medya hesapları için harcandığı ortaya çıkarılmıştır. Dünyada en çok Facebook hesabı olan ülkeler arasında 50 milyona yakın bir hesap sayısıyla yedinci sırada bulunan Türkiye'de bu sayı diğer çeşitli sosyal medya platformlarıyla birlikte daha da artmaktadır. Bu bağlamda eldeki veriler incelendiğinde, bu platformların doğru ve etkili kullanımını önemi ortaya çıkmaktadır.

Dijital platformların fikir alışverişi, haber ve gündemi takip etme ve bilgi alma kaynaklarını çeşitlendirme amaçlı kullanıldığı bu araştırmada ortaya çıkarılmıştır. Lupton (2016) dijital medya araçlarının büyük oranda haber alma, bilgi sahibi olma, bilgiye kolay ulaşma gibi gerekçelerinden dolayı kullanıldığını ifade etmiştir. Koltay (2011) ise dijital platformların içerisindeki zengin ve çeşitli kaynaklar dolayısıyla kullanımının arttığını dile getirmiştir. Okuryazarlığın sosyal bir pratik olarak ele alındığı bu çalışmada okuryazarlığın salt okuma ve yazma olarak kullanımı değil, sosyal etkileşim içerisinde nasıl geliştiği ve kişiler arası ilişkileri etkilediği ele alınmıştır. Bu doğrultuda dijital platformlar bireylerin tanımadığı kimselerle dahi fikir alışverişi yapabildiği, tartışabildiği ya da kaynaklarına erişebildiği alanları barındırdığı için önemli görülmektedir. Aynı zamanda bir okuryazar topluluğu içerisinde gelişen bireylerin kendi okuryazarlıklarının da bu etkileşimden etkilendiği tespit edilmiştir. Rosenthal ve McKeown (2011) tarafından yapılan bir çalışma bireylerin sosyal medyadan etkilenerek yazma stillerinin değiştiğini ortaya koymaktadır. Bu açıdan bakıldığında okuryazarlığın dijital platformlarda kullanımının başka araştırmalar tarafından da ele alındığı ve benzer sonuçlara ulaşıldığı görülmektedir.

Okuryazarlığın günlük hayatı kolaylaştıran, bireylerin işlerini daha düzenli bir şekilde sürdürmesinde yardımcı olan bir yönü bulunmaktadır. Bu yön daha çok çeşitli notlar ve yazma çalışmaları ile yürütülen hatırlatmaları içermektedir. Okuryazarlığın günlük yaşamda kullanımı ele alındığında hatırlatma notlarının önemi daha iyi ortaya çıkmaktadır. Her ne kadar günümüzde çeşitli dijital araçlar sayesinde hatırlatma notları kurulsa bile bu araçlara ekleyeceğimiz hatırlatmalar da yine yazma aracılığı ile gerçekleşmektedir. Motallebzadeh, Ahmadi ve Hosseinnia (2018) araştırmasında bireylerin günlük işleri için okuryazarlığı kullandığını ifade etmiştir. Örneğin bir alışveriş listesi hazırlamak ve alacaklarını unutmamak için yazma becerisi kullanılmaktadır. Yine iletişimi sağlayan bir yapıda olan okuryazarlık yalnızca kendimize yönelik çalışan bir sistem değildir. Bireylerin kendileri dışındaki diğer kişilerle etkileşime geçmesinin de bir yolu olan okuryazarlık farklı kişilere gönderilebilecek hatırlatmaları da içermektedir. Magnifico (2010) araştırmasında bireylerin kendi kendilerine anlatmaktan ziyade başkalarına anlatmak için yazdığını ifade etmiştir. Bu açıdan okuryazarlığın işlevsel bir yönü olan hatırlatmanın günlük hayatta çok sık kullanıldığı ve bu süreçte okuryazarlık becerilerinin işe koşulduğu unutulmamalıdır.

Öğretmen adaylarının okuryazar pratiklerinin en çok yansıdığı alanlarından biri de psikolojik alan olarak tespit edilmiştir. Öğretmen adayları eğlenme, mutlu olma, motive olma ve rahatlama amacıyla okuryazarlığı kullanmaktadır. Baines (2009) düzenli kitap okuyan insanların daha mutlu olduğu ve psikolojik olarak iyi olma haline daha yakın olduğunu ifade etmiştir. Bireyler aslında paylaşması gereken bazı durumları içlerine attıklarında ya da bunları gerektiği gibi ifade edemediklerinde daha stresli olurlar. Bu açıdan özellikle yazma aracılığı ile bireylerin duygu, düşünce ve hislerini ifade etmesi bireye rahatlama duygusu yaşatır. Bu okunan metinler için de geçerlidir. Düzenli okur olan bireyler okudukları kaynaklardan farklı yaşamları, farklı durumları, farklı karakterleri tanır; böylece yaşantısı boyunca kendisini daha mutlu edebilecek durumları iyi analiz eder (Briesemeister, Kuchinke, Jacobs ve Braun, 2015). Bu açıdan bakıldığında okuryazarlığın bireylerin psikolojik iyi olma halleri ile ilişkili olduğu söylenebilir. Aynı zamanda okuryazarlığın günlük yaşam pratiği olarak bu şekilde kullanılması okuryazarlığın bireylerin günlük yaşantısına etkisini göstermesi açısından önemli görülmektedir.

Öğretmen adayları okuryazarlığı sosyal etkileşime geçerek paylaşma, aktarma ve tartışma amaçlı kullandığı görülmektedir. İnsanın sosyal bir varlık olduğu gerçeğinden hareketle bireylerin etkileşime geçmek için okuryazarlığı kullanması gerekli bir durumdur. Bu açıdan öğretmen adaylarının aynı zamanda geleceğin öğretmenleri olarak edindikleri deneyimi, bilgiyi ve pratikleri öğrenciler ile paylaşması, öğrencilerin sosyal ve kişisel gelişimleri açısından önemli görülmektedir. Bu paylaşma ve 
tartışma eyleminin daha nitelikli hale gelmesi şüphesiz ki niceliğinin artması ile de ilgilidir. Birey kişilerarası etkileşime geçerek bir şeyler paylaştıkça bu konudaki becerisi artar ve her geçen gün bu beceriyi daha iyi kullanır hale gelir. Cooper vd., (2014) okuryazar becerileri gelişmiş olan bireylerin sosyal becerilerinin de yüksek olduğunu ifade etmiştir. Bu açıdan bireylerin sosyal becerilerini geliştirmede okuryazarlık bir çözüm yolu olarak da düşünülebilir. Öğretmen adaylarının gelecekte öğretmen olarak görev alacakları düşünüldüğünde bu beceriye ne kadar ihtiyaç duyacağı bilinmektedir. Bu bakımdan öğretmen adaylarının okuryazarlık becerilerini etkin bir şekilde kullanarak sosyal etkileşime geçmeleri önemli görülmektedir.

Yapılan araştırma okuryazarlığı sosyal bir bağlamda ele alması açısından önemli görülmektedir. Çünkü özellikle Türkiye özelinde yapılan çalışmalar incelendiğinde yapılan çalışmaların daha çok okuryazarlık becerilerini geliştirmede kullanılabilecek strateji, yöntem ve teknikler (Arıcı ve Kaldırım, 2015; Baki ve Feyzioğlu, 2017; Doğan ve Müldür, 2014; Karatay, Külah ve Kahya, 2020; Tavşanlı, Yıldırım, Bilgin, Rasinski ve Tschantz, 2020), okuryazarlık becerilerinin ölçülmesine yönelik ölçme araçları geliştirme (Temizkan ve Sallabaş, 2011; Yıldız ve Akyol, 2011) ve okuryazarlığa ilişkin çeşitli paydaşların (öğretmen, öğrenci, veli gibi) görüşlerini alma (Tavşanlı ve Kaldırım, 2018; Yılmaz ve Kadan, 2019) üzerine odaklandığı görülmektedir. Bununla birlikte öğretmen adaylarının okuryazarlığı günlük bir eylem, pratik olarak nasıl ve ne amaçla kullandığı üzerine bir çalışmanın eksikliği hissedilmektedir. Bireylerin okuryazarlık becerileri bir okuryazar topluluğu içerisinde, buradan etkilenilen pek çok faktör ile birlikte şekillenir. Dolayısıyla bireylerin okuryazar pratiklerini incelerken bu faktörleri göz ardı etmek okuryazarlığın bireyde nasıl geliştiğinin anlaşılmasını zorlaştırır. Bu açıdan okuryazarlığın bir okuryazar topluluk içerisinde nasıl şekillendiğinin, bu okuryazar topluluğunun bireylerin okuryazarlığını nasıl etkilediğinin ve bunun günlük yaşama olan yansımalarının ve tüm bunların farklı öğretim düzeyleri ve farklı sosyokültürel yapılar ile çalışımasının gerekli olduğundan hareketle sonraki araştırmalarda bu durumların ele alınmasının yararlı olacağı düşünülmektedir.

\section{Araştırma ve Yayın Etiği}

Bu çalışmada "Yükseköğretim Kurumları Bilimsel Araştırma ve Yayın Etiği Yönergesi" kapsamında uyulması belirtilen tüm kurallara uyulmuştur. Yönergenin ikinci bölümü olan "Bilimsel Araştırma ve Yayın Etiğine Aykırı Eylemler" başlığı altında belirtilen eylemlerden hiçbiri gerçekleştirilmemiştir.

\section{Etik Kurul Izni}

Kurul adı = İstanbul Aydın Üniversitesi Sosyal Bilimler Etik Komisyon Kararı

Karar tarihi= 03.03.2021

Belge sayı numarası $=2021 / 2$

\section{Yazarların Katkı Oranı}

Makale, yazarın kendisi tarafından tek başına hazırlanmıştır.

\section{Çıkar Çatışması}

Çıkar çatışması teşkil edebilecek durum ve ilişki yoktur.

\section{Kaynaklar}

Arıcl, A. F. ve Kaldırım, A. (2015). The effect of the process-based writing approach on writing success and anxiety of pre-service teachers. The Anthropologist, 22(2), 318-327.

Baines, L. (2009). Reading \& happiness. Phi Delta Kappan, 90(9), 686-688.

Baki, Y. ve Feyzioğlu, N. (2017). The effects of digital stories on the writing skills of 6 th grade students. International Online Journal of Educational Sciences, 9(3), 686-704.

Balcı, A. (2015). Karşılaştırmalı eğitim sistemleri. Ankara: Pegem Akademi Yayıncılık.

Barriball, K. L. ve While, A. (1994). Collecting data using a semi-structured interview: A discussion paper. Journal of Advanced Nursing-Institutional Subscription, 19(2), 328-335. 
Barton, D. ve Hamilton, M. (2000). Literacy practices. In D. Barton, M. Hamilton, \& R. Ivanič (Eds.), Situated literacies: Reading and writing in context (pp. 7-15). Routledge.

Basma, B. ve Savage, R. (2018). Teacher professional development and student literacy growth: A systematic review and meta-analysis. Educational Psychology Review, 30(2), 457-481.

Baynham, M. (2004). Ethnographies of literacy: Introduction. Language and education, 18(4), 285-290.

Baynham, M. ve Prinsloo, M. (2009). Introduction: The future of literacy studies. In The future of literacy studies (pp. 1-20). London: Palgrave MacMillan.

Berelson, B. (1952). Content analysis in communication research. Illinois: The Free Press, Glencoe.

Berg, B. L. (2000). Qualitative research methods for the social sciences. Needham Heights: Allyn and Bacon.

Bhola, H. S. (1991). Literacy as a social process; Literacy as a social intervention. ASBAE Courier, 47, 614.

Brandt, D. ve Clinton, K. (2002). Limits of the local: Expanding perspectives on literacy as a social practice. Journal of Literacy Research, 34(3), 337-356.

Briesemeister, B. B., Kuchinke, L., Jacobs, A. M. \& Braun, M. (2015). Emotions in reading: Dissociation of happiness and positivity. Cognitive, Affective, \& Behavioral Neuroscience, 15(2), 287-298.

Cavanagh, S. (1997). Content analysis: Concepts, methods and applications. Nurse Researcher, 4(3), 516.

Christensen, Larry B., Burke Johnson, R. ve Turner, L. A. (2015). Araştırma yöntemleri: Desen ve analiz. (A. Alpay, Çev.). Ankara: Anı Yayıncılık.

Ciampa, K. ve Gallagher, T. L. (2018). A comparative examination of Canadian and American pre-service teachers' self-efficacy beliefs for literacy instruction. Reading and Writing, 31(2), 457-481.

Cooper, B. R., Moore, J. E., Powers, C. J., Cleveland, M. \& Greenberg, M. T. (2014). Patterns of early reading and social skills associated with academic success in elementary school. Early Education and Development, 25(8), 1248-1264.

Craswell, G. ve Poore, M. (2011). Writing for academic success. Sage.

Creswell, J. W. (2012). Educational research planning, conducting and evaluating quantitative and qualitative research. Boston: Pearson.

Digital in 2017: Global Overview. (2017). Erişim Adresi: https://wearesocial.com/specialreports/digital-in-2017-global-overview. Erişim tarihi: 09.02.2021

Doğan, Y. ve Müldür, M. (2014). 7. sınıf öğrencilerine verilen yazma eğitiminin öğrencilerin hikâye yazma becerisine etkisi. Mersin University Journal of the Faculty of Education, 10(1), 49-65.

Downe-Wamboldt, B. (1992). Content analysis: Method, applications and issues. Health Care for Women International, 13, 313-321.

ERG (2017). Eğitim izleme raporu 2016-17. İstanbul: ERG.

Ersoy, A. F. (2016). Fenomenoloji. A. Saban ve A. Ersoy (Ed.). Eğitimde nitel araştırma desenleri içinde. Ankara: Anı Yayıncılık.

Fitzgerald, J., Spiegel, D. L., \& Cunningham, J. W. (1991). The relationship between parental literacy level and perceptions of emergent literacy. Journal of Reading Behavior, 23(2), 191-213.

Flower, L., Stein, V., Ackerman, J., Kantz, M. J., McCormick, K., \& Peck, W. C. (1990). Reading-to-write: Exploring a cognitive and social process. Oxford University Press on Demand.

Graham, S., Liu, X., Bartlett, B., Ng, C., Harris, K. R., Aitken, A. ve ark. (2018). Reading for writing: A meta-analysis of the impact of reading interventions on writing. Review of Educational Research, 88(2), 243-284.

Guo, Y., Piasta, S. B., Justice, L. M. \& Kaderavek, J. N. (2010). Relations among preschool teachers' selfefficacy, classroom quality, and children's language and literacy gains. Teaching and Teacher Education, 26(4), 1094-1103.

Guo, Y., Connor, C. M., Yang, Y., Roehrig, A. D. \& Morrison, F. J. (2012). The effects of teacher qualification, teacher self-efficacy, and classroom practices on fifth graders' literacy outcomes. The Elementary School Journal, 113(1), 3-24.

Huberman, M. A. ve Miles, M. B. (1994). Data management and analysis methods. In N. Denzin \& Y. S. Lincoln (Eds.) Handbook of qualitative research. Thousand Oaks, CA: Sage. 
Jones-Diaz, C. ve Harvey, N. (2007). Other words, other worlds: bilingual identities and literacy. In L. Makin, C. Jones-Diaz, \& C. McLachlan (Eds.), Literacies in childhood: Changing views, challenging practice. Elsevier Australia.

Kamler, B. (2001). Relocating the personal: A critical writing pedagogy. SUNY Press.

Karatay, H., Külah, E., \& Kaya, S. (2020). Okuma alışkanlığını geliştirme yöntem, teknik ve modelleri. Okuma yazma eğitimi araştırmaları, 8(1), 89-107.

Koltay, T. (2011). The media and the literacies: Media literacy, information literacy, digital literacy. Media, Culture \& Society, 33(2), 211-221.

Lincoln, Y. S. ve Guba, E. G. (1985). Naturalistic inquiry. Beverly Hills, CA: Sage.

Lupton, D. (2016). The use and value of digital media for information about pregnancy and early motherhood: A focus group study. BMC pregnancy and childbirth, 16(1), 1-10.

MacCleod, F. (2004) Literacy identity and agency: Linking classrooms to communities. Early Child Development and Care, 174(3), 243-252.

Magnifico, A. M. (2010). Writing for whom? Cognition, motivation, and a writer's audience. Educational Psychologist, 45(3), 167-184.

Matsumura, L. C., Patthey-Chavez, G. G., Valdés, R. \& Garnier, H. (2002). Teacher feedback, writing assignment quality, and third-grade students' revision in lower-and higher-achieving urban schools. The Elementary School Journal, 103(1), 3-25.

Merriam, S. (1998). Qualitative research and case study applications in education. San Francisco: Jossey- Bass.

Miles, M. ve Huberman, A. (1994). Qualitative data analysis. London: Sage.

Motallebzadeh, K., Ahmadi, F. \& Hosseinnia, M. (2018). Relationship between 21st century skills, speaking and writing skills: A structural equation modelling approach. International Journal of Instruction, 11(3), 265-276.

Nelson, J. (1990). This was an easy assignment: Examining how students interpret academic writing tasks. Research in the Teaching of English, 24(4), 362-396.

Pantaleo, S. (2015). Language, literacy and visual texts. English in Education, 49(2), 113-129.

Patton, M. Q. (1980). Qualitative evaluation methods. Beverly Hills, CA: Sage.

Patton, M.Q. (1990). Qualitative evaluation and research methods. London: Sage Publications.

Preiss, D. D., Castillo, J. C., Grigorenko, E. L., \& Manzi, J. (2013). Argumentative writing and academic achievement: A longitudinal study. Learning and Individual Differences, 28, 204-211.

Reiners, G. M. (2012). Understanding the differences between Husserl's (descriptive) and Heidegger's (interpretive) phenomenological research. Journal of Nursing Care, 1(5), 1-3.

Rice, J. K. (2003). Teacher quality: Understanding the effectiveness of teacher attributes. Economic Policy Institute.

Rosenthal, S. ve McKeown, K. (2011). Age prediction in blogs: A study of style, content, and online behavior in pre-and post-social media generations. In Proceedings of the 49th Annual Meeting of the Association for Computational Linguistics: Human Language Technologies (pp. 763-772).

Rubin, H.J. ve Rubin, I.S. (2005). Qualitative interviewing: The art of hearing data. Thosand Oaks: Sage.

Schachter, R. E. (2017). Early childhood teachers' pedagogical reasoning about how children learn during language and literacy instruction. International Journal of Early Childhood, 49(1), 95111.

Selçuk, Z. (2020). Hayatın içindeki müfredat. Millî Eğitim Bakanlığı Yayınları.

Springer, S. E., Harris, S. \& Dole, J. A. (2017). From surviving to thriving: Four research-based principles to build dtudents' reading interest. The Reading Teacher, 71(1), 43-50.

Starkey, L. (2010). Teachers' pedagogical reasoning and action in the digital age. Teachers and Teaching: Theory and Practice, 16(2), 233-244.

Strong, R. W., Silver, H. F., Perini, M. J. \& Tuculescu, G. M. (2002). Reading for academic success: Powerful strategies for struggling, average, and advanced readers, Grades 7-12. Corwin Press.

Tavşanlı, Ö. F. ve Kaldırım, A. (2018). İlkokul 2. sınıf öğrencilerinin süreç temelli yazma uygulamalarına ilişkin görüşlerinin incelenmesi. Ana Dili Eğitimi Dergisi, 6(3), 859-876. 
Tavşanlı, Ö.F., Yıldırım, K., Bilgin, A., Rasinski, T. \& Tschantz, B. (Baskıda). The effect of a PBWMIP on writing success and attitude toward writing. In Reading \& writing quarterly. (Baskıda).

Tavşanlı, Ö.F., Sadioğlu, Ö., Onur Sezer, G. \& Kaldırım, A. (2020). An investigation into how parental literacy experiences are reflected in literacy tendencies and experiences of preservice teachers. International Journal of Progressive Education, 16(5), 138-159.

Tavşanlı, Ö.F. ve Kaldırım, A. (2020). Critical discourse analysis of elementary school teachers' writership identities. International Electronic Journal of Elementary Education, 13(1), 77-88.

Temizkan, M. ve Sallabaş, M. E. (2011). Okuduğunu anlama becerisinin değerlendirilmesinde çoktan seçmeli testlerle açık uçlu yazılı yoklamaların karşılaştırılması. Dumlupınar Üniversitesi Sosyal Bilimler Dergisi, 30, 207-220.

Toptaş, V. (2011). Sınıf öğretmenlerinin matematik dersinde alternatif ölçme ve değerlendirme yöntemlerinin kullanımı ile ilgili algıları. Eğitim ve Bilim, 36(159), 205-219.

Turner, J. ve Paris, S. G. (1995). How literacy tasks influence children's motivation for literacy. The reading teacher, 48(8), 662-673.

Van Bergen, E., De Jong, P. F., Plakas, A., Maassen, B. \& Van Der Leij, A. (2012). Child and parental literacy levels within families with a history of dyslexia. Journal of Child Psychology and Psychiatry, 53(1), 28-36.

Varghese, C., Garwood, J. D., Bratsch-Hines, M. \& Vernon-Feagans, L. (2016). Exploring magnitude of change in teacher efficacy and implications for students' literacy growth. Teaching and Teacher Education, 55, 228-239.

Whitten, C., Labby, S. \& Sullivan, S. L. (2016). The impact of pleasure reading on academic success. Journal of Multidisciplinary Graduate Research, 2(4), 48-64.

Yıldırım, A. ve Şimşek, H. (2011). Sosyal bilimlerde nitel araştırma yöntemleri. Ankara: Seçkin Yayıncılık.

Yıldız, M. ve Akyol, H. (2011). Illköğretim 5. sınıf öğrencilerinin okuduğunu anlama, okuma motivasyonu ve okuma alışkanlıkları arasındaki ilişki. Gazi Üniversitesi Gazi Eğitim Fakültesi Dergisi, 31(3), 793-815.

Yılmaz, M. ve Kadan, Ö. F. (2019). Sınıf öğretmenlerinin süreç temelli yazmaya yönelik görüşlerinin incelenmesi. Akdeniz Eğitim Araştırmaları Dergisi, 13(57), 559-572.

\section{Extended Abstract}

\section{Introduction}

From the moment a person is born, they interact with other individuals in a certain community, and this interaction affects all individuals' lives. This effect is also observed in individuals' literacy experiences. Developing reading and writing skills that affect an individual's life in many areas is considered necessary in all education systems. Because literacy is an active action and reflects individuals' behavior, in this respect, the literacy of individuals is not only affected by the social environment but also affects the social environment through the behaviors they add to the individual. In other words, the individual sends a message to their social environment with their literacy behavior, or these behaviors are perceived by their environment, and a meaning is made from it. This situation is related to literacy being included in individuals' daily life practices (Baynham, \& Prinsloo, 2009).

It is crucial to examine teachers' literacy experiences and reveal how they reflect on their daily lives in a social context. Because the literacy experiences of teachers do not only affect themselves. Teachers' literacy experiences seriously affect their classroom literacy studies, teaching methods, and students' literacy status. Many studies have demonstrated that teachers 'literacy skills affect students' literacy skills (Basma ve Savage, 2018; Ciampa, K. ve Gallagher, 2018; Guo, Connor, Yang, Roehrig ve Morrison, 2012; Pantaleo, 2015; Rice, 2003; Turner ve Paris, 1995).

In this study, the literacy practices of primary school prospective teachers who are likely to work as primary school teachers in the future were examined. As stated in the introduction, one of the most fundamental reasons for this study is that teachers 'literacy experiences are related to their students' literacy, academic success, social life, etc. is the truth of how much impact it has on you. Secondly, when literacy studies are examined, it is seen that literacy is handled more cognitively, and technically, teaching processes are studied more (Tavşanlı et al., 2020). However, it is known that 
reading and writing skills are born as social practices, are affected by social life, and develop with social life. However, this literacy dimension remained in second place in the world, both in Turkey (Flower et al., 1990; Tavşanlı and Kaldırım, 2020). Thirdly, Turkey's educational process has been criticized as irrelevant to real life (Education Reform Initiative, 2017). In this respect, it is a frequently expressed criticism that students do not have the opportunity to apply what they have learned in their real life. In this study, how literacy is used in daily life practices is discussed. Thus, based on the research findings, practical applications for the use of literacy in daily life may come to the fore.

\section{Method}

This research, which aims to examine primary school prospective teachers' literacy practices in a social context, is qualitative research. Six primary school prospective teachers' determined according to specific criteria were included in the study. The study data were collected through semistructured interviews, reflective writings, and sample evidence that they use literacy in their daily lives. The content analysis method was used in the analysis of the research data. Content analysis is defined as a method that focuses on a text's content rather than its visual structure and reveals its internal structures by examining the text in depth (Berelson, 1952; Cavanagh, 1997). Using this analysis method aims to analyze each structure within the texts and reveal the context that these structures reveal and represent and understand what is said in the whole text by revealing the relationships between these structures (Merriam, 1998).

\section{Result and Discussion}

According to the research findings, there are five different ways for primary school prospective teachers to use their literacy practices in daily life. These; academic, digital platforms, daily practices, psychological and social interaction. It has been revealed that prospective teachers use academic literacy in line with their interests, fulfill their homework and responsibilities, succeed in exams, and become more competent individuals. Being an indispensable fact of today's life conditions, digital platforms constitute one of the important themes that prospective teachers mentioned in using literacy. Under this theme, it is seen that literacy studies are carried out to exchange ideas, following the news and the agenda, increasing and diversifying reading resources. Daily practice is one of the themes that necessitate the use of literacy. The necessity for individuals to remind themselves or another person provides this use. One of the reasons for teacher candidates to use literacy was determined as a psychological effect. Under this theme, literacy is used for reasons such as having fun, being happy, motivated, and relaxed. Finally, it was revealed that literacy is used for social interaction. Under this theme, it is seen that literacy skills are used to share and discuss ideas, thoughts, readings, and feelings.

This research was important in terms of addressing literacy in a social context. Because the studies examined, especially in Turkey, which can be used to develop literacy skills of the study it seems to focus on methods and techniques (Arıcı ve Kaldırım, 2015; Baki ve Feyzioğlu, 2017; Doğan ve Müldür, 2014; Karatay, Külah ve Kahya, 2020; Tavşanlı ve diğerleri, 2020). Apart from this, there are studies to develop measurement tools for measuring literacy skills (Temizkan ve Sallabaş, 2011; Yıldız ve Akyol, 2011) and to take the opinions of various stakeholders such as teachers, students, and parents on literacy (Tavşanlı ve Kaldırım, 2018; Yılmaz ve Kadan, 2019). However, there is a lack of a study on how and for what purpose teacher candidates use literacy as a daily action. In this respect, it is suggested to carry out studies that examine how literacy is shaped in a literate community, how this literacy community affects individuals' literacy, and its reflections on daily life. 